\title{
Economics, Helium, and the U.S. Federal Helium Reserve: Summary and Outlook
}

\author{
Steven T. Anderson ${ }^{1,2}$
}

Received 28 August 2017; accepted 4 November 2017 Published online: 5 December 2017

In 2017, disruptions in the global supply of helium reminded consumers, distributors, and policy makers that the global helium supply chain lacks flexibility, and that attempts to increase production from the U.S. Federal Helium Reserve (the FHR) may not be able to compensate for the loss of one of the few major producers in the world. Issues with U.S. and global markets for helium include inelastic demand, economic availability of helium only as a byproduct, only 4-5 major producers, helium's propensity to escape earth's crust, an ongoing absence of storage facilities comparable to the FHR, and a lack of consequences for the venting of helium. The complex combination of these economic, physical, and regulatory issues is unique to helium, and determining helium's practical availability goes far beyond estimating the technically accessible volume of underground resources. Although most of these issues have been analyzed since helium was recognized to be a valuable mineral commodity in the early 1900s, very few economic models have been developed that adequately consider the unique characteristics of helium and helium markets. In particular, there is a notable lack of recent empirical work to estimate the responsiveness of helium demand, supply, prices, and trade patterns to the ongoing drawdown and sale of helium reserves stored in the FHR. In general, existing models of helium either do not account for an oligopoly controlling supply, or they do not evaluate potential helium extraction and storage programs based on an intertemporal maximization of the value of the resource. Such models could be of very limited use to decision makers. This review found only one working paper with a helium market model that has incorporated both of these vital considerations. That and other economic studies along similar lines could be very useful in helping inform current helium policy discussions and decisions.

KEY WORDS: Helium, Economics, Exhaustible resources, Geological storage, Market structure, Oligopoly.

\section{INTRODUCTION}

On June 5, 2017, neighboring countries initiated a trade embargo of Qatar, which had accounted for approximately $32 \%$ of the global helium supply

\footnotetext{
${ }^{1}$ U.S. Geological Survey, National Center, Mail Stop 956, 12201 Sunrise Valley Drive, Reston, VA 20192, USA.

${ }^{2}$ To whom correspondence should be addressed; e-mail: sanderson@usgs.gov
}

prior to the blockade (Croce 2017; Kornbluth 2017b). Even though the United States was the leading supplier of helium in the world, this international development raised concerns about helium shortages and price increases in the country, especially in the scientific research community (Butler 2017; Reisch 2017a). On June 21, the U.S. House of Representatives' Subcommittee on Energy and Mineral Resources held a legislative hearing to hear testimony on a discussion draft of the proposed 
Helium Extraction Act of 2017, which was reportedly aimed at encouraging the development of helium production projects on U.S. Federal lands (Kornbluth 2017a; McDonald 2017; Reisch 2017b; Subcommittee on Energy and Mineral Resources 2017).

With respect to production of an exhaustible natural resource (such as oil, natural gas, and most other minerals), a lower extraction rate leads to slower depletion and greater conservation (underground) as an asset that can accrue value and be available for use by future generations. Most mineral commodities discarded during the production of the main commodity of interest remain located somewhere accessible in or on top of the earth's crust after production of the primary product. From an economics perspective, it is reasonable to expect that such minerals will be (re)extracted from the discard piles and produced whenever it becomes profitable to do so. Helium, however, escapes into the atmosphere during processing or combustion of helium-bearing natural gas, does not present an environmental hazard when it does so, and it could be prohibitively costly to extract from the air far into the future (National Research Council 2000), except in special circumstances (Clarke and Clare 2012). Currently, the predominant (economic) source of helium is that contained in natural gas. Thus, substantial volumes of helium resources could be effectively lost to both current and future consumers, whenever the host natural gas is produced and the helium content is vented (Nuttall et al. 2012).

Helium is an exhaustible natural resource for which there are limited or no substitutes including for its use as a coolant in military aircraft, certain types of nuclear reactors; the manufacture of optical fiber and semiconductors; providing low enough temperatures for superconducting magnets; enabling modern magnetic resonance imaging (MRI) technologies to operate; other cryogenic applications; and in other applications (Cai et al. 2012). Because of its unique properties, helium is expected to continue to be essential in enabling the development of such critical technologies in the future [APS Panel on Public Affairs and Materials Research Society (APS and MRS) 2011; American Physical Society, Materials Research Society and American Chemical Society (APS, MRS, and ACS) 2016]. Separation of helium from production streams of natural gas and storage underground can conserve it for potentially vital applications in the future. Currently, however, helium reserves previously stored in the U.S. Federal Helium Reserve (the FHR) are being extracted and sold without replacement, in order to fulfill requirements in the Helium Stewardship Act (HSA) of 2013 (Burton 2017).

Different approaches to addressing the issues with helium result in very different answers to the key questions of what the intertemporal allocation of helium resources should be, what the role of government should be, and how uncertain future demand for (and supply of) helium could evolve. Deciding how much helium to store in the FHR (or elsewhere) depends on the answers to these questions (Epple and Lave 1980). When the provisions of the 2013 HSA were being decided, only a few rigorous studies of the economics of helium were available, and their usefulness to decision makers is uncertain. Included in this review is a brief summary of a working paper by Massol and Rifaat (2016), in which the authors rigorously consider a more realistic representation of current helium market conditions than found in past studies. This and other new economic studies could help better inform potential future helium policy decisions.

The following section is a review of potentially applicable models from the field of natural resources economics. The subsequent sections detail the currently available data and information on helium resources, supply, demand, relevant institutions, and market structure, and provide some interpretation of what these imply for helium markets. This paper concludes with a discussion of the potential implications suggested by the findings of this review in the form of an outlook for helium markets and provides suggestions for future research.

\section{ECONOMICS AND HELIUM}

The fundamental principle of the economic theory of exhaustible resources was derived by Hotelling (1931). This principle is often called the "Hotelling Rule", and it is generally represented by some form of the following equation (Dasgupta and Heal 1979; Devarajan and Fisher 1981).

$$
P(t)=P_{0} e^{r t}
$$

In Eq. 1, $P(t)$ is the (spot) price of one unit of the resource in period $t, P_{0}$ is the initial price (at $t=0$ ), and $r$ is the rate of interest. Hotelling (1931) showed that the price of an exhaustible resource must grow 
at the rate of interest when the intertemporal extraction rate of the resource is efficient (such that the present value of the resource cannot be increased by reallocating its extraction among periods relative to the current extraction program) and the resource industry is in competitive equilibrium (Solow 1974). The key assumptions used to derive Eq. 1 were that the objective of the resource extraction firm is to maximize its net present value (NPV), the structure of ownership and production of the resource is perfectly competitive, and the interest rate is constant (Nuttall et al. 2012).

\section{Imperfect Competition}

Hotelling (1931) also considered the market structures of monopoly and oligopoly, and he showed that a monopolist would tend to extract the resource at a lower rate than a competitive firm (Devarajan and Fisher 1981). Since then, there have been many comparisons of optimal extraction rates across different ownership structures (e.g., Dasgupta and Heal 1979). Although some studies in the literature have described cases where a monopolist could be expected to extract an exhaustible resource at an efficient rate, extraction of an exhaustible natural resource is generally expected to be inefficient (and at a lower rate) if controlled by a monopoly or oligopoly, where the rate of extraction by a monopolist is expected to be the lowest. The rate of extraction under oligopoly is generally found to be greater than that of a monopolist, but it is expected to tend toward the monopolist rate the fewer the number of firms or the greater the extent of cartelization of the extractive industry (Tietenberg 2003).

Although helium production is not controlled by a cartel, the firms producing this exhaustible resource could still be considered an effective oligopoly (Cai et al. 2010). Generally, more than five producers have been deemed necessary for the market structure not to be considered an oligopoly (Nuttall et al. 2012). From 1937 to 1960, the U.S. Bureau of Mines (USBM) was the only (significant) producer of helium in the world (U.S. Government Accountability Office 2015), and fewer than five major producers have controlled the helium market since 1990 (Kornbluth 2015, 2017c). Helium is a byproduct of natural gas processing, and it may exist in small proportions (generally $<0.3 \% \mathrm{He}$ ) in most conventional natural gas fields (Cook 1979). Epple and Lave (1980) assumed that there could be many potential entrants into helium production, at least partially because there existed many private owners of helium-bearing natural gas deposits (at the time). Since then, however, the USBM and (subsequently) the U.S. Bureau of Land Management (BLM) have reported that only a very small percentage of major conventional gas fields in the United States have been estimated to contain $>0.3 \% \mathrm{He}$, which is generally considered to be the minimum helium content necessary for the separation and production of helium contained in natural gas to be profitable (APS, MRS, and ACS 2016).

\section{Consideration of Storage}

Given the unique properties of helium, the main adjustment that has been made to theoretical and applied models of exhaustible resources is to include the possibility of storing (rather than simply venting) excess helium. This complicates theoretical models by adding the decision of how much helium to store to the firm's objective function, and applied models may then have to estimate the potential impact of the availability and costs of storage on the quantity of helium produced, consumed, exported, and so forth. The following is a review of how some authors have built upon Hotelling's (1931) seminal work, or modified other models of exhaustible resources for application to the helium industry.

\section{Maximizing the Value of Helium}

In general, the objective of this class of models is to determine the rate of extraction that maximizes the present discounted value of the (utility of the) exhaustible resource. Epple and Lave (1980) extended existing models of the economics of natural resources to include the choices of storing the volume of extracted helium that is not currently used, or to produce it from the atmosphere (at a far higher cost) in the future. Their key assumptions were perfect competition in helium supply by private firms with access to secure storage at negligible costs, five potential sources [with costs ranging from $\$ 7$ per thousand cubic feet (MCF) of helium extracted from natural gas to $\$ 1600$ per MCF He extracted from air], and deterministic growth rates of demand of either $2 \%$ (low demand growth) or 3\% (high demand growth). The most important variable 
in their model was the current productivity of capital (equal to the discount rate, $r$ ), and they performed their analysis for a number of scenarios with alternative discount rates of 2,5 , and $10 \%$, respectively. Their main result was that it is not optimal to separate and store helium that is not already being separated from natural gas (or could be separated very cheaply via existing helium production circuits in natural gas processing plants) unless the discount rate is zero. That is, zero venting of helium is not optimal in their model unless the estimated current productivity of capital invested in the economy (equal to the discount rate) is less than or equal to zero.

If private helium producers do not have access to secure storage (for example, at the FHR near Amarillo, Texas), then Epple and Lave (1980) suggested that the Government could have a role in contributing to helium market efficiency by just providing helium storage capacity at cost, but that the Government could distort market efficiency if it were also determining helium prices or levels of storage. Pindyck (1982) extended their argument to show that there should be no stockpiling of helium (or any other exhaustible resource) for purely economic reasons, even in the presence of ongoing demand uncertainty. The underlying assumption is that the Government should not be able to store resources more cheaply than private (competitive) firms. An example of a situation where such an assumption might hold could be in the event that there is nothing geologically unique about the Bush Dome reservoir in the Cliffside field near Amarillo, Texas (the storage location of the FHR). In this case, every helium-producing firm in the United States could theoretically reinject any unsold helium onsite (storing it in the reservoir where it was originally extracted from), and re-extract it as needed.

Regarding their deterministic model, Epple and Lave (1980) warned that the estimates of demand growth that they used were subject to a great deal of uncertainty, including uncertainty about the development of game-changing technologies (like development of commercially viable nuclear fusion technology), which could cause demand for helium to increase at far greater rates than they assumed. Hughey (1989) included this type of demand uncertainty in her model and showed how competitive owners of helium-rich natural gas reserves could choose to conserve both resources underground in anticipation of far greater returns to extracting the joint resource after a jump in the price of helium (owing to development of a technology that would substantially increase demand for helium). Uncertainty in her model was only regarding the timing of this expected jump in demand of helium, not in the magnitude of the sudden increase in quantity demanded at that time. Pindyck (1982), however, assumed that there would be random fluctuations in the quantity of helium demanded continuously over time.

In their recent working paper, Massol and $\mathrm{Ri}$ faat (2016) rigorously considered the oligopolistic nature of the helium industry in their model, and treated the FHR and the few other major helium producers in the world as players in a dynamic noncooperative game. They simulated the major helium suppliers' behavior under two different policy scenarios, one meant to represent fulfilling the requirements of the 2013 HSA [including depletion of the FHR to 3 billion cubic feet (BCF) and ceasing commercial operations by end-2021 (Hamak 2016a)], and an alternative policy that would allow the FHR to be operated as a profit-maximizing enterprise until about 2034. Based on results from a variety of simulations of their model, the authors suggest that the alternative policy could increase Federal revenue, lower helium venting, and increase global welfare compared to that under the 2013 HSA.

\section{Social Versus Private Discount Rates}

The type of demand uncertainty that Hughey (1989) assumed led to the helium resource owners in her model effectively using a lower rate of discount than in the deterministic case. In their sensitivity analysis, Epple and Lave (1980) found that the current productivity of capital (= the private discount rate of perfectly competitive firms, $r$ ) had the greatest impact on the results of their model. The recent study by Massol and Rifaat (2016) was the only one found in this review that allowed different helium producers to have different discount rates. In their model, the authors assumed that (potential) producers in OECD countries had a discount rate of $7 \%$; in non-OECD countries, $10 \%$; and the BLM's discount rate was equal to a social discount rate of $3 \%$. In general, the results of economic models of exhaustible resources depend critically on the authors' assumptions regarding the discount rate. The social rate of discount may be approximately equal to the 
private discount rate of perfectly competitive firms (Baumol 1968), but there are instances where they are likely to be quite different, such as in the presence of significant differences between social and private risk (Jensen and Bailey 1972; Tietenberg 2003).

The higher the social rate of discount, the greater is the value to society of current extraction and use of an exhaustible resource relative to that of leaving it underground (or storing it) for use by future generations. The lower the social rate of discount, the greater is society's economic incentive to conserve more of the current stock of the resource for future use. If the current productivity of capital invested in the economy $(r)$ is an appropriate proxy for the social rate of discount, then (Epple and Lave 1980)'s results suggest that the return to current investment would have to be approximately zero in order for it to be optimal to separate and store all helium contained in extracted natural gas. As a result of the study of 13 energy critical elements (ECEs), however, the APS and MRS (2011) recommended that the United States should maintain a stockpile of helium (alone), and not of any of the other ECEs. Other scientists and economists (e.g. Pigou 1929; Daly 1977) have even suggested that it could be immoral to vent helium, because it could prohibitively increase the cost to future generations without even being utilized by the current generation (Cook 1979). If helium is really unique, this could imply that society should apply an effectively lower discount rate for optimal management of helium relative to that applied in the use of other exhaustible resources.

Some authors have mentioned a few policy approaches that could potentially reduce the discount rate resource owners apply to helium production and conservation decisions. For example, Page (1977) suggested that a severance tax could be implemented to encourage greater conservation, and Epple and Lave (1980) suggested that a policy like decreasing the profit tax rate applied to profits from helium production could reduce the private discount rate with respect to helium production. Three different subsidies (a helium sales subsidy, a helium storage subsidy, and a helium separation subsidy) were compared by Hughey (1991), and she suggested that (of these three subsidies) a helium sales subsidy could have the greatest benefit to helium markets net of estimated adverse effects on natural gas markets.

\section{Empirical Work}

Empirical studies of helium markets (e.g., Howland and Hulm 1974; Liu 1983; Uri 1986) are still too few and very dated. Empirical estimates of the responsiveness of helium demand and supply to price, demand growth rates, and other characteristics of helium markets have contributed to the calibration of theoretical models. For example, Howland and Hulm (1974) estimated that the quantity of helium consumed might decrease by only $3 \%$ if producers' increased price by $10 \%$ (and prices were below $\$ 100$ per MCF of helium to begin with). Uri (1986) tried to improve on earlier studies by identifying the inter-dependent relationships among demand, supply, and the volume of helium in storage. He found that helium supply could be significantly more responsive to changes in helium price than the results of earlier empirical studies might suggest.

The responsiveness of helium demand to price can be measured as the price elasticity of demand $(\varepsilon)$, which is defined as the percent change in quantity demanded divided by the percent change in the price. It is commonly written in the form of the following equation:

$$
\varepsilon=\frac{p}{q} \frac{\Delta q}{\Delta p},
$$

where $p$ is the price (of helium), $q$ is the quantity demanded, $\Delta q$ is the change in the quantity demanded, and $\Delta p$ is the change in price. Using Eq. 2, Howland and Hulm (1974)'s estimate of the responsiveness of helium demand to a change in price could be expressed as $\varepsilon=-0.03 / 0.1$ (which is equal to an estimated price elasticity of demand for helium of - 0.3). If the demand elasticity is less than one in absolute value, then demand is defined as inelastic (Varian 1990). In general, empirical estimates of the price elasticity of demand for helium suggest that the demand for helium is highly inelastic, which could be mostly owing to a lack of substitutes. Given time, consumers could theoretically find more substitutes, and the long-run elasticity of demand for a normal good is generally expected to be greater than in the short run. In addition, technological innovations can occur over time that increase efficiency of use, and less-heliumintensive technologies can be substituted for current ones. However, Uri (1987) estimated the long-run elasticity of demand for helium to only increase to 
0.63 (in absolute value) compared with a short-run elasticity estimate of 0.5 .

\section{Other Helium Models}

Cai et al. (2010) used the methodology of industrial or systems dynamics (Forrester 1951; Sterman 2000) to describe the dynamics of the helium market and potential responses to changes in policies. In their analysis of an integrated system that included a production model, an investment model, a market model, a demand model, and other submodels, the authors tried to account for many factors that could be important to the evolution of helium markets, including the effects of changes in the production of conventional natural gas, the development of helium-intensive technologies, and the rates of helium being vented during natural gas processing and combustion on the rate of depletion of helium resources. Their analysis suggested that helium production could accommodate increasing consumption until about 2030, plateau until depletion of helium resources forces a gradual reduction in production (possibly not until after 2060, depending on the amount of venting), and decrease more or less steadily until natural gas fields with extremely low He content and the atmosphere become the primary sources of helium by about 2100 . Nuttall et al. (2012) suggested modifications to the demand submodel of Cai et al. (2010) to better tie aggregate demand to the behaviors of individual agents.

Instead of modeling helium markets using a systems dynamics approach, which relies heavily on feedback effects at an aggregate level to define the state of the system (Macal 2010), Riddle et al. (2016) developed a prototype agent-based model of the helium market, which used the attributes and behaviors of individual agents (including the BLM and private helium producers) to derive responses of the entire system in various scenarios. Their model could also be used to consider a market structure of oligopoly in helium supply. The preliminary results from their prototype model suggest that helium stored in the FHR could be mostly depleted by about 2029, but that the United States could still be a significant exporter of helium (owing to increasing production by private U.S. helium producers).

Nuttall et al. (2012) suggest that a systems dynamics approach is well suited to consider market structures like oligopoly, for which it might not be possible to derive analytical solutions using a (more narrow) microeconomics approach. However, the authors did note some issues with Cai et al. (2010)'s model of helium markets, including the lack of an endogenous component to account for short-term helium market shocks. A recent example of this type of shock on the supply side could be the 2017 trade embargo on Qatar (Croce 2017; Reisch 2017a). In addition, Nuttall et al. (2012) suggested that Cai et al. (2010)'s model did not include a component to analyze the impacts of some longer-term structural changes (such as ongoing developments in the production of shale gas, which generally does not contain significant amounts of helium [Clarke et al. 2013]). Similarly, the prototype agent-based model of Riddle et al. (2016) accounted for the impacts of expected pricing behaviors of just a few producers on helium markets, but did not account for potential impacts of significant short-term or extended shortfalls in supply from the major domestic or foreign sources of helium. The authors did recognize this issue and suggested some model improvements and data needs to address it.

In the late 1980s, Uri (1987) argued that there was a great need for more empirical studies of helium markets that should be soundly based on current data and institutional considerations. Recently, Massol and Rifaat (2016) noted that more empirical work on helium economics is still much needed and that there is a severe lack of applied theoretical work and other economic studies of the global helium market. With respect to resources and production, Mohr and Ward (2014) argued that more accurate projections of the future availability of helium supplies are needed. The 2013 HSA directed the BLM, the U.S. Geological Survey (USGS), and other entities to complete a national assessment of helium resources, provide current information on the expected future availability of domestic supply, assess current and projected trends in domestic and global helium demand, and provide other updates to data and information about current and future helium resources and markets (U.S. Government Printing Office 2013; Brennan et al. 2017).

\section{RESOURCES}

Helium is mostly found in low concentrations within natural gas, another exhaustible natural resource. Although they can be found in the same geologic traps, the two commodities originate from 
different sources. Common helium (helium-4) is formed as a result of radioactive decay of uranium and thorium (Brown 2010), while natural gas (thermal methane) is a fossil fuel that is gradually released from hydrocarbon source rocks. Thus, natural gas production by hydraulic fracturing of those source rocks (shales, and so forth) instead of conventional production by extracting it from geologic traps will not generally result in significant helium production or additional access to helium resources (Whiticar 1994). Like helium-4, helium-3 forms as a result of radioactive decay, but the most common source of helium-3 is as a byproduct of maintenance operations on nuclear weapons. Helium-3 occurs in extremely low concentrations in nature, even lower than helium-4 (Shea and Morgan 2010).

\section{Classification of Helium Resources}

The following definitions from USGS Circular 831 (U.S. Bureau of Mines [USBM] and U.S. Geological Survey [USGS] 1980) on principles of resource and reserve classification are important to consider in a discussion of the current state of helium resources (USGS 2017).

Resource-A concentration of naturally occurring solid, liquid, or gaseous material in or on the Earth's crust in such form and amount that economic extraction of a commodity from the concentration is currently or potentially feasible.

Reserve Base-That part of an identified resource that meets specified minimum physical and chemical criteria related to current production practices, including those for grade, quality, thickness, and depth.

Reserves-That part of the reserve base which could be economically extracted or produced at the time of determination. The term reserves need not signify that extraction facilities are in place and operative.

Economic-This term implies that profitable extraction or production under defined investment assumptions has been established, analytically demonstrated, or assumed with reasonable certainty.

In addition, guideline 16 in USGS Circular 831 (USBM and USGS 1980) concerning the classification of mineral byproducts is very impor- tant to classifying helium resources. "In classifying reserves and resources, it is necessary to recognize that some minerals derive their economic viability from their coproduct or byproduct relationships with other minerals. Such relationships must be clearly explained in footnotes or in an accompanying text."

As a byproduct of the production of natural gas (methane) from conventional reservoirs, the economics of helium production depends on that of the other components in the gas stream in a complicated way. Markets for those other potential commodities (including $\mathrm{CO}_{2}$, nitrogen, sulfur, and the methane, itself), availability of adequate storage capacity, and other factors can all influence what part of the helium content of that natural gas is considered a viable resource. To evaluate all of these factors and estimate the current volume of helium that can be considered as resources or reserves is a very formidable task, especially at a national or regional scale (National Research Council 2000; USGS 2017).

\section{Helium in the Atmosphere}

Venting of helium during the production of natural gas is unlike possibly analogous decisions to discard potential byproducts that are not currently economic from mineral production streams. For example, a zinc producer could revisit discard piles or tailings of indium-containing zinc mine output that were not economic to process (with respect to producing either the zinc or indium) when it was initially mined. The mined material remains available (often at a very low storage cost), until it is profitable to (re)process the discard piles at some future time (e.g., when there is a sufficient increase in the price of indium). As such, the currently subeconomic indium content of the discard piles could still be considered as a potentially economic source of indium (APS and MRS 2011).

It is technically feasible to extract helium from the atmosphere using currently available cryogenic technologies. Thus, it is conceivable that helium vented during the processing of natural gas could still be considered as a technically accessible source of helium. A possible analog for how to classify helium in the atmosphere could be how to classify lithium present (in low concentrations) in the ocean. Both are technically feasible to recover, but far enough removed from being commercially viable to 
only be classified as subeconomic (APS and MRS 2011; Martin 2015; Jaskula 2016; USGS 2017). At some point, the costs of transforming resources into marketable commodities enter into the classification of the resource, and it is highly uncertain when or if a major cost-reduction will take place to be able to consider it economic to extract helium from the air as a primary product. In addition, changes in demand could possibly increase users' willingness to pay for helium enough to make it economic to extract helium from the air.

The equilibrium concentration of helium in the atmosphere is about 5 parts per million (ppm). According to Zahnle and Catling (2009), helium leaks out of earth's atmosphere, but it is replaced by evaporation from the Earth's crust at a rate sufficient to maintain this equilibrium concentration. Anthropogenic releases (venting) of helium have not been found to have had a significant impact on the $5 \mathrm{ppm}$ atmospheric helium level (Clarke and Clare 2012). At such a low level of concentration, extraction of helium from the air as a primary product is generally considered to be prohibitively expensive and could remain so far into the future (National Research Council 2000; Clarke et al. 2012). As such, helium in the atmosphere is not likely to meet the USGS definition of a resource (USBM and USGS 1980) any time soon, unless it is being considered as a potential byproduct of other gases (including argon, neon, krypton, xenon, and others) that could be considered profitable to extract from the air (National Research Council 2000; Clarke and Clare 2012).

\section{Shale Gas}

Helium is formed underground by radioactive decay (of uranium and thorium) and can become trapped along with methane and other natural gases (including $\mathrm{CO}_{2}$ and nitrogen) if the caprock is impermeable enough to trap tiny helium molecules (as is the case with the Bush Dome reservoir in the Cliffside field). The natural gas contained in these traps comes from a different source (the hydrocarbon source rock) (Whiticar 1994). Even where helium generated by decay of nearby radioactive elements is caught in the same trap as hydrocarbon gas, the share of helium in the total volume of trapped gasses is extremely low (Brown 2010). Still, it could be economic to separate and produce even extremely lean helium content (as low as $0.04 \% \mathrm{He}$, or even $0.015 \% \mathrm{He}$ ), if the natural gas were to be used to produce liquefied natural gas (LNG) (National Research Council 2010; Waltenberg 2013; Brennan et al. 2017). Thus far, reports of even such miniscule levels of helium content in natural gas that has been produced directly from hydrocarbon source rocks by hydraulic fracturing are not available (Clarke et al. 2013), and increasing use of this "shale gas" to produce LNG is not likely to result in any significant additions to helium resources.

\section{Helium Resource Estimates}

In 2017, the BLM reported in the annual USGS Mineral Commodity Summaries (MCS) chapter on helium that total estimated helium resources in the United States were about 20.6 billion cubic meters (based on data available as of December 31, 2006). This resource estimate did not consider helium in the atmosphere. It just included the estimated helium content of conventional natural gas reservoirs. The BLM has also estimated total helium resources in the rest of the world to be about 31.3 billion cubic meters, so helium resources in the United States accounted for about $40 \%$ of the world total. The other leading locations for helium resources in the world were Qatar, which was estimated to contain 10.1 billion cubic meters of helium resources (about 19\% of the world total); Algeria, 8.2 billion cubic meters (about 16\%); and Russia, 6.8 billion cubic meters (13\%). No other country was estimated to contain more than Canada's 2 billion cubic meters of helium resources (about $4 \%$ of the world total) (Hamak 2017).

In an attempt to account for the higher costs of producing helium contained in lower concentrations in natural gas, Cook (1979) multiplied the volume of helium identified in natural gas reserves by the estimated concentration level of helium in that natural gas in order to derive what he labeled as helium resource value units (HRVUs). Without including helium resources for the Tip Top field (which Cook suggested could contain more HRVUs than he estimated for the rest of the United States, combined), he found that the United States could have accounted for about $52 \%$ of the total HRVUs in the world in 1978. Cai et al. (2010) applied Cook's method of estimating HRVUs to more recent reserves data from the MCS (Pacheco 2008) and estimated that the country could have accounted for about $36 \%$ of the world's total helium resources (as measured in HRVUs) in 2003. 


\section{USGS and BLM Helium Information}

The same estimate of total U.S. helium resources and reserves has been reported in the MCS since 2009 (Pacheco 2009) and is reportedly based on data as of December 31, 2006 (Hamak 2017). As part of the requirements of the Helium Stewardship Act of 2013, the USGS was required to complete a national-level assessment of subsurface helium resources in the United States. As an initial component of the assessment process, the USGS has compiled a publically available database of helium concentrations and locations based on a compositional analysis of discovered subsurface gas in the country, with a majority of the data taken from the USGS geochemical database and from the BLM natural gas database. The new database includes all gas analyses with measured values of helium. Those with measured concentrations of $<0.005 \% \mathrm{He}$ are listed as "TRACE", and those with $\geq 0.005 \% \mathrm{He}$ were rounded up to $0.01 \% \mathrm{He}$ in the new database. The helium concentration values in this database are based on analyses of gas samples from wells, and they do not necessarily represent the concentration of helium in the entire reservoir (Brennan et al. 2017). Although the wells are geolocated in the new database, more information is needed to estimate the volume of helium in each reservoir, and the geographical distribution of helium resources (by volume) in the United States.

Until more information becomes available, the map in Figure 1 roughly reflects the current understanding of the regional distribution of helium resources in the country (APS, MRS, and ACS 2016). Figure 1 is based on helium discovered as of the mid-1970s, and it is not clear whether the gas fields on the map that contain less than $0.3 \% \mathrm{He}$ have high enough helium concentrations to be economic to produce it as a byproduct of LNG production. Data and information on more recent helium discoveries and developments are included in the MCS helium chapter (Hamak 2017) and in the helium chapter in the USGS Minerals Yearbook (Hamak 2016a).

\section{Helium Reserves}

Based on data as of December 31, 2006, Hamak (2017) reported a total of about 4.25 billion cubic meters of measured helium reserves in the United States, and he reported a slightly lower estimate of about 3.9 billion cubic meters of helium reserves contained in the natural gas fields that currently account for most of the helium produced in the country. According to the MCS, the country has the leading volume of helium reserves in the world. However, the USGS does not directly measure mineral reserves (even in the United States), and neither companies nor governments directly report mineral reserves to the USGS. In addition, different countries apply different criteria and use slightly different definitions for mineral reserves data. So, mineral (including helium) reserves data are difficult to compare across countries, even if they are reported (USGS 2017).

Qatar has the third-ranked volume of conventional natural gas reserves in the world (behind Russia and Iran) and could be presumed to have large helium reserves as well (Flower 2012). According to Hamak (2017), data on Qatar's helium reserves are not available. Since Qatar produces helium as a byproduct of LNG, the country can profitably produce helium present in natural gas at concentrations as low as $0.04 \% \mathrm{He}$. How much of this helium can be considered reserves is difficult to estimate. Hamak (2017) does report an estimate of 1.8 billion cubic meters of helium reserves in Algeria (which also produces helium as a byproduct of LNG), 1.7 billion cubic meters in Russia, and 0.025 billion cubic meters in Poland.

\section{Nondepleting Helium Reserves}

The National Research Council (2000) of the National Academy of Sciences (NAS) reported that the BLM estimate of 6 billion cubic meters of measured U.S. helium reserves as of December 31, 1996 (Gage and Driskill 1998) included nondepleting helium reserves (known He content of natural gas that was not being developed because of a lack of marketability of any of the components of the gas) and helium that was being vented or expected to be vented (either during the purification of helium-bearing natural gas for use as fuel, or as a result of the combustion of that fuel). The National Research Council (2000) attempted to account for both of these important factors using a resources-reserves classification scheme like that used in the petroleum industry (Society of Petroleum Engineers 2017) and suggested that proven helium reserves in 1996 in the United States could have been only about 4 billion cubic meters (two-thirds of the BLM estimate).

Newell et al. (2009) defined low-British thermal units (BTUs) natural gas as having less than 950 


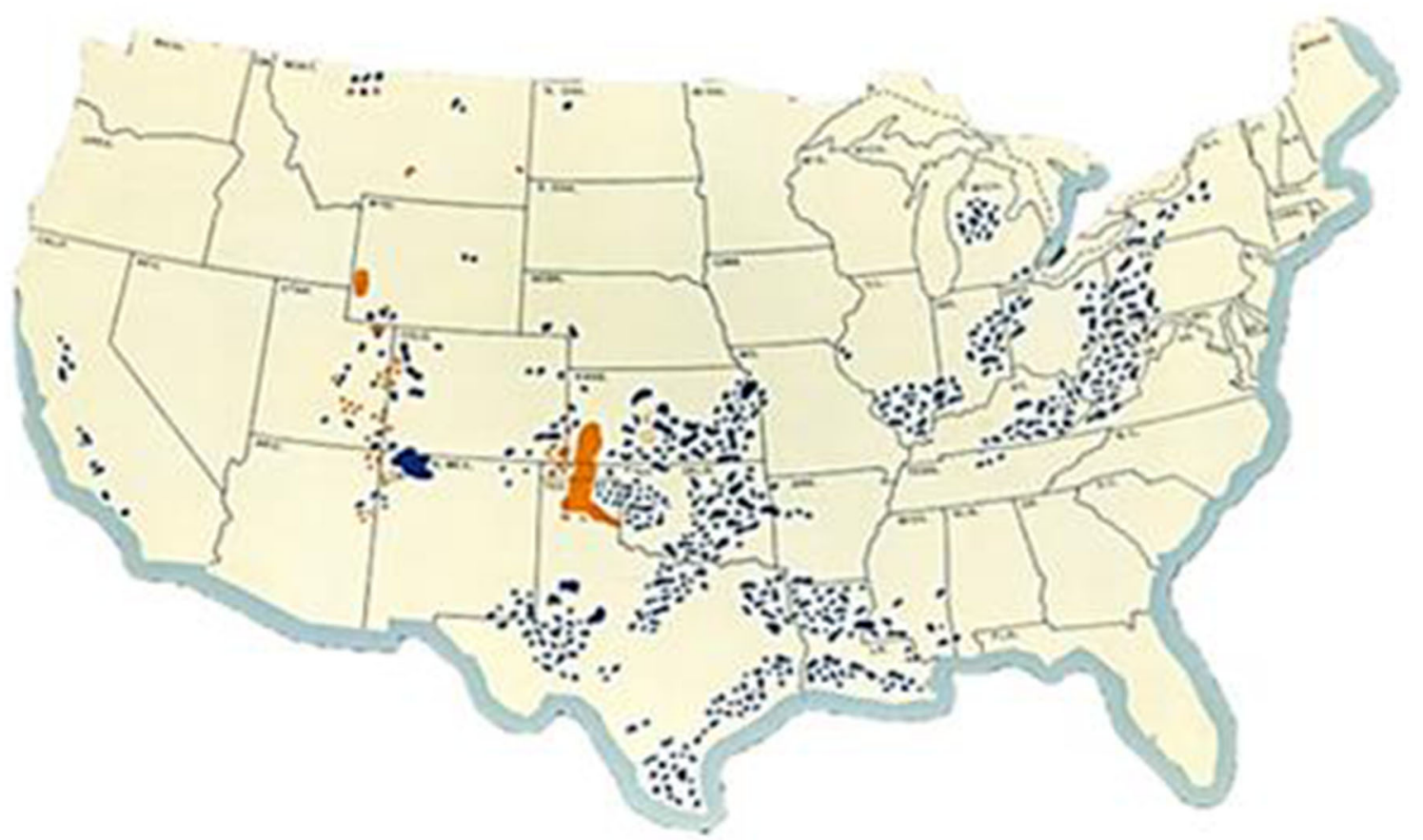

Helium contentless than $0.3 \%$

Helium content $0.3 \%$ or greater

Figure 1. Major gas fields of the United States. Image courtesy of the U.S. Bureau of Land Management, at https://www. blm.gov/nhp/300/wo310/images/major_gasfields-US.jpg.

BTUs per standard cubic foot (scf) (about 33,500 BTUs per cubic meter). The term "nondepleting" applies to helium reserves contained in low-BTU natural gas (Gage and Driskill 1998). The National Research Council (2000) suggested that the nondepleting helium reserves contained in low-BTU gas fields in the Riley Ridge area of Wyoming were not likely to be produced in the foreseeable future. Since then, however, Exxon Mobil Corp. (ExxonMobil) has increased production of low-BTU gas in the area [including for the purpose of extracting the $\mathrm{CO}_{2}$ in the gas to be utilized for enhanced oil recovery (EOR)] (Carbon Capture and Sequestration Technologies 2016), and the company's Shute Creek plant that processes the gas has become the leading helium production facility in the United States (Sears 2012; Exxon Mobil Corp. 2016). The National Research Council (2000) suggested that its motivation for trying to estimate the level of proved helium reserves was that the terminology used by BLM (Gage and Driskill 1998) to classify resources and reserves made it difficult to understand how much helium could be 'potentially available.' Since the timing of development of projects such as ExxonMobil's LaBarge gas project near Riley Ridge is highly uncertain, it could be preferable to include nondepleting reserves in estimates of helium reserves, but still describe what part is depleting and nondepleting. This is what Gage and Driskill (1998) did, and this appears to be consistent with guideline 16 in USGS Circular 831 (USBM and USGS 1980) for classifying reserves and resources of potential byproducts.

\section{Storage and Venting}

In general, helium is a very minor component of natural gas production streams and cannot be managed separately according to the market conditions for helium unless there is availability of storage capacity with adequate seals to prevent leakage of helium for an extended period of time (National Research Council 2000, 2010). For the few helium 
resource owners with access to the FHR, helium storage and re-extraction costs could be quite low, but storage costs could be much higher for most of the world's helium producers. Helium is an extremely inert element. It does not cause significant problems to consumers if it is left in natural gas (in low concentrations) to be vented into the atmosphere upon combustion of the gas, and helium in the atmosphere does not cause any environmental concerns. Natural gas processing plants already have purification circuits installed to separate and vent helium (if necessary) during purification of the gas into a marketable commodity. As such, large volumes of helium that have not been needed to supply current market demand have frequently been vented rather than stored (Clarke et al. 2013).

The National Research Council (2000) argued (in effect) that helium that is expected to be vented should not be included in estimates of reserves (or separately accounted for as depleting reserves), even if it is originally present in high enough concentrations in natural gas for it to be potentially economic to produce. In addition, Tietenberg (2003) noted that the level of potential helium reserves crucially depends on how much of it can be expected to be stored (instead of vented). Whether helium destined to be vented is accounted for in reserves estimates or not, the lack of consequences for helium venting and the limited availability of long-term helium storage to (potential) producers are important issues to consider in order to project the future availability of helium (Mohr and Ward 2014).

So far, the FHR is reportedly the only largescale, long-term helium storage facility in the world, and the ability to store helium there is a vital factor in determining the potential level of helium reserves in the United States (National Research Council 2010). To conserve (rather than vent) helium in order to be able to re-extract it in the future, it could be possible for natural gas producers to inject extracted natural gas (containing helium) or just the (separated) helium itself back into the natural gas reservoir to be stored there until the helium price rises enough to make it profitable to re-extract. However, reports of injection of extracted gas onsite for the purpose of storing helium are not available, which could indicate that injection of extracted helium on private sites to store it for future re-extraction is generally not economic. Construction of a rival helium storage facility that would be of comparable scale to the FHR also does not appear to have been economic at any time since the FHR became fully operational in 1962 (Sears 2012), even given no reason to expect that the geologic characteristics of the Bush Dome reservoir that allow storage of helium at Cliffside field are unique in the world.

In 2016, Air Liquide S.A. commissioned a small-scale helium storage facility in a salt cavern in Germany to be able to streamline near-term deliveries (Healy 2016), but this temporary storage of helium for delivery would not be counted as helium reserves in the country. Gazprom plans to construct helium storage facilities in eastern Russia (Gazprom 2017), but the timeline for development of this project is uncertain (Garvey 2017). New development of a large-scale storage facility capable of securing helium for an extended period of time and the infrastructure for (potential) helium producers to access that storage capacity could be prohibitively costly (APS, MRS, and ACS 2016). Leading up to completion of the FHR in the early 1960s, U.S. demand for helium increased rapidly, including the quantity demanded by the U.S. military for applications such as liquid fuel rockets for defense and space exploration (Sears 2012). Since then, sufficient market (and political) forces have not conspired to be able to overcome the huge investment hurdle and incentivize development of a helium storage complex comparable to the FHR anywhere else. This could be at least partially owing to periods of accelerated sales of helium from the FHR, which could have resulted in some suppression of helium price increases at various times during the existence of the FHR, including during implementation of the Helium Privatization Act of 1996 (National Research Council 2010). The unrivaled existence of the FHR could be mostly owing to first-mover investments in the pipeline, refineries and other facilities that form the complex system, and not that dependent on the geologic characteristics of the site.

\section{SUPPLY}

Even if the ownership structure of U.S. supply of natural gas is considered perfectly competitive, that of the supply of helium in the country could be far less so (Uri 1986). The costs to obtain the rights to develop the limited potential of economic production of helium from only a few natural gas reservoirs (Fig. 1) could combine with significant capital costs (to begin separation, transportation, 
and storage of helium contained in natural gas) to create substantial barriers to entry. Since the early 1960s, when the U.S. Government ceased being the only significant supplier of helium in the world, the historical tendency of global helium supply has been that 4-5 (or even fewer) major helium producers supplied $80 \%$ (or more) of global and U.S. consumption (Liu 1983; Kornbluth 2015, 2017c). This evidence suggests that the structure of the helium industry may be best characterized as an oligopoly, at least at some points along the value chain from resource to refined helium (Cai et al. 2010; Nuttall et al. 2012).

\section{Crude Helium}

In 2015 (the latest year for which data were available), total sales of helium produced in the United States amounted to about 88 million cubic meters, including the withdrawal and sale of about 22 million cubic meters of helium that had been stored at the FHR; in 2014, total sales of helium produced in the country was 101 million cubic meters, of which 22 million cubic meters was also withdrawn from the FHR. In 2015, total sales of U.S. helium accounted for about $56 \%$ of the world's supply (by volume) during the year compared with about $62 \%$ in 2014 , and the U.S. share of the global helium supply is estimated to have decreased again (slightly) in 2016 (Hamak 2016b, 2017). At the beginning of the trade embargo on Qatar in 2017 (which caused a suspension of helium exports by the country), analysts expected that the FHR would not be able to ramp up extraction of helium enough to be able to replace more than a very small portion of the sudden shortfall in global supply (Croce 2017; Reisch 2017b).

Injection of crude helium into the Bush Dome reservoir at Cliffside field reportedly began in 1945 (Sears 2012), but programmatic storage (conservation) of helium there was minimal until amendments to the 1925 Helium (Conservation) Act were enacted by Congress in 1960 (and came into effect in 1961). The 1960 amendments to the 1925 Helium Act required the U.S. Government to undertake an extensive helium conservation program at the FHR (Cai et al. 2010). Since then, empirical studies (e.g., Liu 1983; Uri 1986, 1987) indicate that operation of the FHR (including purchases, storage, and sales of helium) has been a very important (if not the most important) component of the global supply of crude helium (Kornbluth 2015).

In 2016, the posted price for allocated and nonallocated sales of crude helium from the FHR continued to serve as the primary benchmark for a majority of worldwide sales of liquid and crude helium, and the BLM has used the average auction price result to set the posted price since the BLM helium auctions began in 2014. Thus, sales of helium from the FHR continued to be the leading factor in determining worldwide helium prices, despite the decreasing U.S. share of global supply (Kornbluth 2016). In July 2017, the BLM held probably its penultimate auction of helium from the FHR, and the average auction price (set equal to the posted price for allocated and non-allocated sales later in the year) was $\$ 119$ per MCF, which was $11.2 \%$ (about $\$ 12$ per MCF) higher than in 2016. Since the auction in 2018 will likely be the final one, helium industry analysts expect the average auction price (and therefore the allocated sales price) to be incrementally higher (Garvey 2017).

\section{Byproduct}

In 2014 (the latest date for which these data were available), the main companies that owned or operated plants that produced helium and were attached to the BLM helium pipeline included DCP Midstream LLC (Midstream), Linn Energy LLC, and Pioneer Natural Resources Co. The main source of production of crude helium (not re-extracted from storage) for the pipeline and the facilities attached to it was the Hugoton gasfield, which stretches across Oklahoma, Kansas, and Texas. In 2014, other (potential) sources of crude helium under or around the BLM pipeline included the Cliffside, Fain, and Panhandle West fields in Texas; the Keyes field in Oklahoma; and the Greenwood, Panoma, and Reichel fields in Kansas (Hamak 2016a). Helium reserves in the Hugoton field are reportedly in decline (Clarke et al. 2013). Estimated helium reserves and resources in all U.S. gasfields are likely to change pending the results of the forthcoming USGS national helium gas assessment (Hamak 2017).

In 2016, the leading helium production facility in the United States was ExxonMobil's Shute Creek processing plant in Wyoming. The Shute Creek plant is part of the company's LaBarge natural gas production and processing facilities. The company 
extracts the feed gas for the Shute Creek plant from the Tip Top, Madison, and Hogsback gasfields (Sears 2012; Exxon Mobil Corp. 2016). In addition to the price of helium, the economics of the natural gas extraction and processing operations at LaBarge also heavily depends on the market value of the methane and $\mathrm{CO}_{2}$ present in the extracted gas. A portion of the extracted $\mathrm{CO}_{2}$ is sold for use in nearby enhanced oil recovery (EOR) operations (Carbon Capture and Sequestration Technologies 2016). The LaBarge operations are not attached to the BLM helium pipeline, and the crude helium separated there is refined on site to produce Grade-A helium for transportation in containers.

Another U.S. helium production operation that is not attached to the BLM pipeline is Air Products and Chemicals, Inc. (APCI)'s Doe Canyon operation in Colorado, where helium is separated from a natural gas stream that consists mostly of $\mathrm{CO}_{2}$ (Air Products and Chemicals, Inc. 2015). Kinder Morgan Inc. transports the natural $\mathrm{CO}_{2}$ from Doe Canyon to New Mexico and West Texas to be used for EOR (Kinder Morgan Inc. 2017). Thus, the economics of the Doe Canyon natural gas extraction and processing operation also depend on revenue streams from sales of other commodities in addition to that of helium. Analysis of two gas samples taken near St. Johns, Arizona suggested that the predominantly $\mathrm{CO}_{2}$ gas there could contain potentially commercial amounts of helium (Rauzi 2003; Clarke et al. 2013). In 2014, Kinder Morgan planned to develop the St. Johns field mainly as a $\mathrm{CO}_{2}$-source for EOR. In 2015, however, Kinder Morgan suspended development of the St. Johns field, reportedly because of poor $\mathrm{CO}_{2}$-EOR market conditions related to low oil prices (Kinder Morgan Inc. 2015; Passut 2015).

In general, natural gas resources have not been developed with the primary intent of extracting the helium. Unique opportunities to sell natural $\mathrm{CO}_{2}$ for EOR in the United States have led to the development of a few low-BTU gas operations that produce helium, but helium may not have been the primary target even in these cases. Instead, the economics of these operations often depend on the relative concentrations and prices of all the components of the low-BTU natural gas. The Harley Dome low-BTU gas reservoir in eastern Utah was reportedly designated as (part of) "Federal Helium Reserve No. 2" by the President of the country in 1934, but IACX Energy LLC (IACX) first reported marketable production of helium there in 2013. The company estimated that the helium content was relatively high (about 7-8\%), but that the rest of the gas was mostly nitrogen. Despite the high estimated levels of helium in Harley Dome and expectations of increasing helium prices during earlier phases of the project, it was still necessary for IACX to complete development of a small-scale, low-pressure helium extraction technology to be able to profitably produce the helium (Cockerill 2013; Oil and Gas Journal 2013).

\section{Liquefied Natural Gas}

Cai et al. (2010) noted that the distribution of global helium production was shifting strongly toward helium extracted during the processing of natural gas to produce LNG. Since their study, global helium production has shifted significantly toward a greater share that is associated with production of LNG. In 2016, Algeria and Qatar (where helium is entirely a byproduct of LNG production) accounted for about $40 \%$ of the world's total estimated production of helium (Hamak 2017), compared with about $15 \%$ in 2007 (Pacheco 2009).

On February 24, 2016, the United States exported its first shipment of LNG produced in the lower 48 States, and there are additional U.S. natural gas liquefaction plants and LNG export terminals currently under construction, proposed, or pending approval of permit applications with the Federal Energy Regulatory Commission. There was no reported helium production associated with this new production of LNG in 2016, and it could be that very little (if any) new helium production will result from these planned increases in production of LNG in the country. The new U.S. production of LNG for export is in response to increasing production of shale gas in the country since 2006, which has helped to lower domestic prices for natural gas relative to foreign prices. Together with new legislation allowing U.S. exports of LNG, this has encouraged development of new LNG production and export infrastructure (U.S. Energy Information Administration 2016). However, the feed gas for this new LNG production is expected to mostly (if not exclusively) consist of shale gas, which does not generally contain even the minimal content of helium ( 0 . $015-0.04 \% \mathrm{He}$ ) that is likely necessary for profitable helium production during natural gas processing to produce LNG (Clarke et al. 2013). 


\section{The Backstop}

If the economics of production of He-containing natural gas warrant it, natural gas producers may extract, process and transport the natural gas solely in response to market conditions for natural gas; independent of consideration of current or future demand for any helium contained within. In this case, all of the helium content could be vented into the atmosphere as a natural gas impurity during processing or eventual combustion of the fuel (National Research Council 2000). The last resort to bring that helium back into the supply chain requires extracting helium from the open air. Economists often call such a production technology of last resort a "backstop" (Nordhaus 1973).

The cost of producing helium by itself from the air has been estimated to be anywhere from $\$ 1000$ per MCF to $\$ 9000$ (or more) per MCF of He (Cook 1979). Epple and Lave (1980) assumed $\$ 1600$ per MCF for extracting helium from the air as the cost of the backstop supply in their model. The cost of the backstop in their model was 15 times as high as producing helium from very lean-He natural gas and about 230 times greater than for producing helium from He-rich gas. More recently, Clarke and Clare (2012) suggested that newer technologies could produce a small amount of helium (about $1-2 \%$ of 2012 global helium production) from the atmosphere at a cost as low as about $\$ 200$ per MCF He, but only if helium were a byproduct of the production of argon, neon, krypton, xenon, or other gases in the air. In addition, this would not contribute significantly to satisfying helium demand. Helium extraction from the atmosphere to only produce helium or to produce in volumes commensurate with expected demand is not generally considered economic with current technologies (Cook 1979; National Research Council 2000; 2010)

\section{Refined Helium}

Crude helium is present in varying concentrations in the FHR, and it has to be further refined to be marketable. There are only six helium refineries that straddle the BLM helium pipeline, and they supply Grade-A helium after extraction and processing crude helium extracted from the FHR. A provision in the 2013 HSA requires these "refiners" to make excess refining capacity available at commercially reasonable rates to "non-refiners" (com- panies that do not own refining capacity on the BLM pipeline), but the 2013 HSA does not require refiners to report information on negotiations with nonrefiners that do not result in signed agreements to lease out excess refining capacity. As a result of one BLM helium auction and two subsequent sales during the summer of 2014, only refiners purchased crude helium from the FHR, and complete information on negotiations to make excess capacity available to non-refiners was not available. At least through 2014, only refiners on the BLM helium pipeline appeared to supply Grade-A helium produced from crude helium that was extracted from the FHR (U.S. Government Accountability Office 2015).

\section{Production Capacity}

Reported data on the total current helium refining capacity on the BLM pipeline were not available, but Kornbluth (2016) suggested that production capacity of those refineries could have been about 4 billion cubic feet per year (BCF/year) of liquid helium at one time. In July 2014, refiners on the BLM helium pipeline reported that they expected to have a total of about 790 million cubic feet (MMCF) of excess refining capacity during fiscal year 2015 (FY2015), although they were not required to fully disclose how much excess capacity they had unless they actually succeeded in contracting it out to non-refiners (U.S. Government Accountability Office 2015). All of the approximately 93 MMCF of helium sold during BLM's auction in July 2014 for distribution in FY2015 was purchased by refiners on the pipeline (U.S. Bureau of Land Management 2014b). In addition, refiners purchased about $835 \mathrm{MMCF}$ of helium via BLM's posted-price sale for delivery through the pipeline in FY2015 (U.S. Bureau of Land Management 2014a).

As of December 31, 2014, Hamak (2016a) reported that there was an estimated total U.S. GradeA helium production capacity of 132 million cubic meters $(\times 36.053$ cubic feet per cubic meter $=$ approximately $4.76 \mathrm{BCF})$. Of this total U.S. refined helium production capacity, ExxonMobil's Shute Creek plant reportedly had the capacity to produce at least 4 MMCF of helium per day (Sears 2012), which could amount to about $(4 \times 365=) 1.46 \mathrm{BCF} /$ year. If so, the production capacity of the refineries on the BLM pipeline could have been only about 3.3 $\mathrm{BCF} / \mathrm{year}$, and the Shute Creek plant alone could 
have accounted for about $30 \%$ of the reported Grade-A helium production capacity in the United States. Any other helium refineries not attached to the BLM pipeline are relatively small, including APCI's Doe Canyon plant in Colorado, which reportedly had a designed capacity to produce about 230 MMCF per year (MMCF/year) of helium (Air Products and Chemicals, Inc. 2015; Garvey 2017).

\section{Ownership Structure}

In 2015, APCI was the world's leading helium supplier, and other major suppliers to the global helium market include Linde Global Helium Inc. (Linde), Praxair Inc. (Praxair), and ExxonMobil (Goldberg 2015). Available data and information suggest that these four companies also own most of the U.S. capacity to produce Grade-A helium (Hamak 2016a), and the ownership of helium production capacity in the United States (and the world) will become even more concentrated if the planned merger of Linde and Praxair is approved (Capitol Forum 2016; gasworld Business Intelligence 2017; Trager 2017). At least through 2016, the annual posted-price sales of crude helium from the FHR were allocated to the few refiners that have a direct connection to the BLM helium pipeline according to their share of the total helium refining capacity attached to the pipeline. According to BLM data on allocated sales in August 2015, APCI owned about $36 \%$ of the total helium refining capacity on the BLM crude helium pipeline; Praxair, 34\%; Linde, 26\%; and Midstream, 4\% (U.S. Bureau of Land Management 2015). According to BLM data on allocated sales in August 2016, IACX's new helium plant near Otis, Kansas, also had access to the BLM helium pipeline. This recent addition only added about $1 \%$ to the total refining capacity on the pipeline in 2016 and did not significantly change the shares controlled by the existing refiners (U.S. Bureau of Land Management 2016).

\section{Entry}

The few major firms producing Grade-A helium could maintain an oligopoly if the costs of entry are high enough. Like for most mineral resources projects, the costs of discovering and developing new helium resources are substantial, and it takes a number of years from the time of discovery and verification of the resource to be able to produce a marketable commodity. In the meantime, markets fluctuate and create price uncertainty that can create an incentive for a firm with a monopoly (or as part of an oligopoly) to delay before sinking the necessary large capital costs in the project (Dixit and Pindyck 1994).

The time, effort, and costs to secure the property rights and leases also contribute to the barriers to entry. The high helium content of the Harley Dome gasfield in Utah was recognized by 1924 (or earlier), but helium was not produced there until 2013 (PRNewswire 2013; IACX Energy LLC 2016). In addition to technical issues with the project, the president of upstream helium production at IACX reportedly suggested that negotiations with the Government to obtain the rights to produce helium from this field had been extensive (Reisch 2017b). On June 21, 2017, the Subcommittee on Energy and Mineral Resources of the U.S. House of Representatives held a legislative hearing on a discussion draft of a bill to allow helium extraction from natural gas on Federal lands under the same lease terms as oil and gas (Kornbluth 2017a; McDonald 2017; Subcommittee on Energy and Mineral Resources 2017).

Qatar has been producing LNG since 1996, is the leading producer of LNG in the world, and has been extracting helium as a byproduct of LNG production since at least 2005. Algeria began producing LNG and helium as a byproduct of LNG even before Qatar (Flower 2012; Kornbluth. 2015). In 2017, U.S. production of LNG was still in a nascent stage, and LNG producers in the United States did not appear to pose much of a threat of entry into the global (or U.S.) helium supply chain. Even if there is $>0.04 \% \mathrm{He}$ in many of the U.S. gasfields in Figure 1, the capital costs to develop LNG production together with helium separation, storage, and transportation infrastructure that would source from those gasfields will contribute to the barriers to entry of potential U.S. LNG producers into the helium market.

\section{Helium-3}

A small number of Governments that maintain arsenals of nuclear weapons control a vast majority of the supply of helium-3. Generally, extraction of helium-3 from underground sources is considered uneconomic, because it is far more scarce and it 
appears in far lower concentrations than common helium (helium-4) (Clarke and Clare 2012). Other potential sources of helium-3 include tritium (as a byproduct in heavy-water nuclear reactors, production of either tritium or helium-3 using particle accelerators, and (like helium-4) extraction of naturally occurring helium-3 from natural gas or the atmosphere. Generally, these other sources of helium-3 have also not been considered economic in the presence of sufficient supply from nuclear weapons maintenance operations.

Shea and Morgan (2010) suggest that the economics could change if demand for helium-3 increases sufficiently. In addition, the current supply of helium-3 exhibits a disconnect with the market for it, because the timing of the weapons maintenance may occur on a fixed schedule that has little or nothing to do with fluctuations in demand for helium-3. Regarding the issue of storage, however, the volumes of helium- 3 being produced and consumed are far smaller than that for helium-4, and it is possible to store produced helium-3 in small flasks (measured in liters) to meet future demand. Again, that situation could change if there is a significant increase in demand for helium-3 (Shea and Morgan 2010).

\section{Oligopoly}

To summarize the ownership structure for the supply of helium, there appear to be instances of oligopoly at various points along the helium supply chain (Nuttall et al. 2012), especially for supply of purified (Grade-A) helium and of helium-3. Depending on the degree to which regulators force Linde and Praxair to divest in order to complete their planned merger, the ownership structure of helium production in the United States (and the world) will probably become even more concentrated in the very near future (Capitol Forum 2016; gasworld Business Intelligence 2017; Trager 2017). In addition, the BLM's planned disposal of all helium-related assets by no later than the end of fiscal year 2021 (APS, MRS, and ACS 2016; Hamak 2017) could increase the market power of the few remaining producers of crude helium (if the FHR is sold to one of the existing major helium producers or a consortium of existing helium majors). In 2016, one new LNG plant and export terminal started up in the country, although more are planned to possibly come onstream in the country in the not too distant future (U.S. Energy Information Adminis- tration 2016). As currently planned, however, these new LNG producers are not likely to contribute significantly to the total helium supply in the United States (or the world), and the ownership structure of helium supply in the near future is still likely to be best characterized as an oligopoly.

\section{DEMAND}

With only a few major helium producers in the world and the FHR being the only helium storage facility of its kind (National Research Council 2000, 2010; McDonald 2017), major helium supply disruptions have occurred, and it is reasonable to expect that they will continue to occur in the future (Kornbluth 2015, 2016). Helium users have adapted and will need to continue to adapt to improve efficiency of use, containment, and recycling of helium (Butler 2017; IHS Markit 2016b). Owing to its unique physical properties, however, there are still no substitutes for helium in many cryogenic applications (including enabling superconductors and MRI machines to function) and other applications (Hamak 2017). In addition, the future availability of economic sources of helium could be necessary to enable development of emerging and future technologies that could be critical to the U.S. and global economy (APS and MRS 2011; APS, MRS and ACS 2016).

\section{Trends}

In 2015, estimated global helium consumption was about 6 BCF (APS, MRS and ACS 2016), remained at about that level in 2016, and was still expected to stay at about that level in 2017. Through 2022, global helium consumption is expected to grow by about $1.5 \%$ per year (Garvey 2017). Throughout the 1990s, rapid development of MRI technology was the main driver in double digit growth in helium consumption. In the 2000s, innovations in MRI technologies made MRI machines much more efficient at using helium, including by way of reducing the boil-off of helium during their operation (gasworld 2014). Development of alternative technologies and increased recycling of helium has also increased efficiency of use in the cryogenic applications sector (including the MRI industry). Despite this increased efficiency, however, the continuing increases in the deployment and use of MRI systems 
have meant that the MRI industry is still the leading consumer of helium in the world (Sears 2012; Kornbluth 2015; APS, MRS, and ACS 2016; Garvey 2017).

\section{Technology}

There are no substitutes for helium in cryogenic applications if temperatures below $-429^{\circ} \mathrm{F}$ are required (Hamak 2017). In order to attain the necessary superconductive state, the magnets in MRI scanners need to be cooled to a temperature that can be attained only by using helium (IHS Markit 2016b). In 2015, MRIs accounted for $20 \%$ of worldwide consumption; this was followed by use in analysis and spectrometry, $15 \%$; a sector that included leak detection, pressurization, purging, and other uses, $15 \%$; use as a lifting gas, $14 \%$; the electronics and semiconductors sector, $11 \%$; diving (for breathing mixtures), $6 \%$; fiber optics, $6 \%$; science and engineering research, $6 \%$; welding, $5 \%$; and use in controlled atmospheres, $2 \%$ (APS, MRS and ACS 2016) In 2016, the MRI industry continued to lead helium use in the United States, accounting for about $30 \%$ of U.S. consumption of Grade-A helium. Helium's importance in MRIs was followed by its use as a lifting gas, which accounted for 17\% of 2016 U.S. consumption; analytical and laboratory applications, $14 \%$; welding, $9 \%$; engineering and scientific applications, 6\%; leak detection and semiconductor manufacturing, $5 \%$ each; and various other applications (including purging and pressurization), 14\% (Hamak 2017). Globally, the MRI industry is expected to continue to decrease its consumption of helium relative to consumption by the electronics industry, including for the manufacture of semiconductors, liquid crystal displays, and fiber optics (Garvey 2017).

In 1963 (when the U.S. space and missile programs were the primary helium users), pressurization of liquid-fueled rocket engines (which required large amounts of helium for pressurizing and purging the fuel tanks) was the leading use of helium, and it accounted for about $42 \%$ of U.S. consumption; it was followed by welding, $14 \%$; use in controlled atmospheres $12 \%$; science and engineering research, $10 \%$; use as a lifting gas, $6 \%$; leak detection, $4 \%$; cryogenics, $3 \%$; and no other use accounted for greater than $3 \%$. In the 1970 s, the U.S. space program decreased its activities in general, and hard fuels were developed and increasingly substituted for liquid fuels in rocket propulsion. From 1984 to 1999, however, the National Aeronautics and Space Administration (NASA) again increased its purging and pressurization demand, including use of about 7.5 MMCF of helium for each Space Shuttle launch (Cai et al. 2012). By 2015, cryogenic applications (including MRIs) accounted for $32 \%$ of total U.S. helium consumption; pressurizing and purging, $18 \%$; controlled atmospheres, $18 \%$; welding cover gas, $13 \%$; leak detection, $4 \%$; breathing mixtures, $2 \%$; and other uses, 13\% (Hamak 2016b).

In scientific and engineering research, helium is used extensively (for its cryogenic properties) in NMR Spectroscopy, and NMR instruments are reportedly in use in almost every research university in the United States. NMR Spectroscopy is heavily used in the research fields of medicine, chemistry, pharmacology, and physics. This technology is reportedly being used to enable the synthesis of organic chemicals that have led to new drugs and other essential products. In addition to its more familiar cryogenic properties, a lesser known property of helium is that it does not become radioactive when exposed to radiation. This makes it potentially critical in the development of advanced nuclear reactor technologies for power generation (APS and MRS 2011; Cai et al. 2012; APS, MRS, and ACS 2016).

\section{Geographical Distribution}

In 2001, the United States accounted for about $60 \%$ of global helium consumption; countries in Europe and the Middle East, 22\%; Japan, 11\%; other countries in Asia, 4\%; and the rest of the world, 2\%. In 2010, the United States accounted for about $41 \%$ of global helium consumption; countries in Europe and the Middle East, 32\%; Japan, 3\%; other countries in Asia, 21\%; and the rest of the world, 3\%. In 2016, IHS Markit (2016a, b) projected that future helium demand would shift more toward the electronics manufacturing sectors in China, the Republic of South Korea and Taiwan. In 2017, helium consumption in Asian countries (including in these 3 major helium consumers) was expected to surpass U.S. helium consumption for the first time. In 2017, Asian countries were expected to consume about 1.94 BCF of helium compared with about 1.9 BCF in the United States (Garvey 2017). IHS Markit (2016a, b) expected that global helium consumption could increase at about $2 \%$ per year 
through 2020, but that consumption in these three countries could increase by about $4 \%$ per year during the same time period.

\section{Uncertainty}

Helium could be potentially critical to the development of a commercially viable fusion technology, and development of this widely sought after energy technology could potentially raise helium consumption far beyond any current projections (Hughey 1989). However, the timing of development of commercially viable fusion technology is highly uncertain (Epple and Lave 1980; Cai et al. 2012). In addition, the fusion reactors would likely have to be designed to include an extensive capability to recycle helium, since consumption of helium for fusion could quickly outstrip supply. So, any future helium demand related to development of fusion technology is highly uncertain for many reasons. Significant increases in helium demand could occur in the nearer term as NASA continues to develop its Space Launch System (SLS). The SLS is currently designed to use liquid hydrogen fuel, which requires helium for purging and pressurizing the system, but it is possible that the design of future launch systems could not require as much helium (National Aeronautics and Space Administration 2017).

From 2011 through 2013, the helium market experienced shortages, and some long-term supply contracts were only filled at $70-80 \%$ of the contracted delivery volumes. In 2014 and 2015, however, the helium market was described as in surplus, and this was expected to continue through at least 2017. Part of the reason for this lingering surplus was reported as owing to demand destruction during the shortage (IHS Markit 2016b). Since substitution for helium in most applications may be possible to only a limited extent, this sluggish recovery in demand could be mostly owing to more efficient use of helium, and partially owing to greater efforts and investments in recycling (APS, MRS, and ACS 2016).

Despite the reported surplus of helium (Kornbluth 2016), the American Physical, Materials Research and American Chemical Societies (2016) reported that ongoing volatility of prices and inconsistent supply were still limiting research crucial to the development of innovative technologies. Helium prices may not adjust as quickly as expected to current market conditions owing to the prevalence of long-term supply contracts with take-or-pay arrangements (Cai et al. 2012). In addition, helium prices may increase as a greater share of global production shifts to countries that may have greater political uncertainty than in the United States. Garvey (2017) reported that part of the reason there was an $11.2 \%$ increase in the average BLM helium auction price could have been because the Qatar blockade could have created a premium for U.S. helium over that from other sources.

\section{Helium-3 Demand}

Many uses of helium-3 for medicine, industry, and science are similar to that for helium-4, such as its use in medical imaging. There are some unique cryogenic applications and research that require helium-3, because it liquefies at an even lower temperature than helium-4 (APS, MRS, and ACS 2016). Importantly, helium-3 also has unique value as a neutron detector, an application for which helium-4 may be a poor substitute. Detectors that rely on helium-3 are used to detect (concealed or smuggled) nuclear and other radiological material, and were increasingly deployed in the United States following the terrorist attacks of September 11, 2001. This increase in demand raised concerns about potential shortages of helium-3 (Shea and Morgan 2010).

\section{Criticality Debate}

The American Physical Society and Materials Research Society (2011) recommended that the United States should maintain a nondefense stockpile of helium, but not of any of the 13 other energy critical elements (ECEs) that they identified. They suggested that helium is unique even in comparison with other ECEs, because it is unlikely that any economic source of helium besides natural gas will be found, helium is often vented into the atmosphere during the production and consumption of natural gas, and natural gas production (without separation of helium) and consumption is likely to continue to increase. Since then, natural gas production and consumption in the country has increased, but that has been mostly owing to increases in the production of shale gas, which may not have any significant helium content. However, if produc- 
tion of shale gas declines and natural gas prices rise enough to bring more conventional gas production onstream, then there could be an increase in helium venting in the country (Clarke et al. 2013).

As amended through 2016, helium was not included in the list of strategic and critical minerals for the purposes of the Strategic and Critical Materials Stock Piling Act (50 U.S.C. § 98 et seq.). The two parts of the definition of the term "strategic and critical materials" in this Act were that the material "would be needed to supply the military, industrial, and essential civilian needs of the United States during a national emergency", and that it is "not found or produced in the country in sufficient quantities to meet such need" (DLA Strategic Materials 2017). Through 2016, it could be that enough helium was being produced in the country (Hamak 2017) that helium did not meet the second part of this definition. The European Union, for example, has added helium to their list of critical minerals, and this could be because they are more dependent on imports for helium supplies than the United States.

As of November 2017, reports of significant decreases in the availability of helium in the United States during the trade embargo on Qatar were not available. The FHR was still in operation and selling helium to private consumers during this time, but it is uncertain to what extent helium sales from the FHR could make up for even a small part of a shortfall caused by any prolonged absence of Qatari supply (Croce 2017; Kornbluth 2017a, b; McDonald 2017; Reisch 2017a; Subcommittee on Energy and Mineral Resources 2017).

\section{OUTLOOK}

In July 2017, the BLM held its FY2018 crude helium auction. In the summer of 2018, the BLM is scheduled to hold its final auction and conservation sales of crude helium stored in the U.S. Federal Helium Reserve (the FHR). After this, no further sales of crude helium from the FHR to private industry are scheduled, and the volume of reserves in place there is expected to reach the targeted volume of $3 \mathrm{BCF}$ of helium after final deliveries are made to the private sector during FY2019 (Burton 2017). Private U.S. suppliers of helium could increase production to make up for some of the decrease in BLM supply, but a greater share of global helium production is likely to continue to shift to other countries. As of mid-2017, reports of development of rival helium storage facilities that could be comparable to the FHR were not available. If alternative storage facilities are not developed before the FHR is closed to private consumers, it is unlikely that the global helium industry will be able to compensate for a sudden loss of one of its few major suppliers (such as Qatar).

In 2018, the second-leading helium producer in the world (Qatar) is scheduled to bring its third major helium production plant onstream, and this plant is expected to produce about $425 \mathrm{MMCF} / \mathrm{year}$ of helium. Qatar produces helium as a byproduct of LNG, and the global supply of helium could continue to trend toward major LNG producers. For projections of future helium production by LNG producers, it is important to recognize that LNG production from shale gas is not likely to contribute much (if any) to helium production, since shale gas has not been found to contain significant amounts of helium. As of mid-2017, nascent LNG production in the United States was based on shale gas. If shale gas continues to be the major source of LNG production in the country, this could also be a minor contributor to further decreases in the share of U.S. production in global helium supply. Gazprom has developed a project to produce a large amount of helium from natural gas in eastern Russia, but the timeline to startup of production is uncertain, at least partially owing to uncertainty surrounding the future price of the natural gas. Another project to produce helium contained in natural gas in South Africa has been announced, and there are reportedly plans to develop the recent helium discovery in Tanzania. However, these projects are remotely located and still in the planning stages, and information on projected timelines for development was not available (Garvey 2017).

Natural sources of the helium-3 isotope appear to be even more limited than that of helium-4, and substitutes for some important uses of helium-3 (such as for detection of radioactive material and leaks) could be even more rare than for helium-4. In response to elevated concern about the availability of helium-3 in the United States in the 2000s (Shea and Morgan 2010), the USGS was tasked with assessing helium-3 resources (U.S. Government Printing Office 2013). As of 2017, however, reports of severe shortages of helium-3 were not available, and these concerns may have decreased somewhat. Ongoing maintenance activities on arsenals of nuclear weapons could be enough to satisfy future 
demand for helium-3. If not, it appears unlikely that enough helium-3 from natural sources could be produced to contribute significantly to any severe shortfalls in supply.

In general, demand for helium has been increasing in the United States, and this trend could continue even with increased recycling and efficiency of use in the country (APS and MRS 2011; APS, MRS, and ACS 2016; IHS Markit 2016a, b). Despite an estimated $20 \%$ increase in apparent consumption of helium in the country in 2016 compared with that of 2015 (Hamak 2017), the U.S. share of global demand may continue to decrease. Alternatively, potential increases in NASA's demand, continuing scientific and engineering research demand, and stable demand for use in critical cryogenic applications could mean that the country will continue to be one of the leading helium consumers in the world for some time. Although U.S. imports of helium did not account for a significant share of the country's apparent consumption in 2016, imports could increase in the near future. If so, helium could satisfy criteria to be more widely considered as a critical or strategic mineral in the United States.

The ownership structure of helium supply is likely to become even more concentrated with the planned merger of Air Products and Linde (gasworld Business Intelligence 2017), and the scheduled disposal of all BLM helium assets by the end of FY2021 (Hamak 2017). There has been a historical lack of economic models of helium markets that consider the implications of an oligopoly being in control of the supply of this potentially critical resource. Since about 2010, however, a few economic models have appeared in the literature that consider oligopolistic control of the supply of helium. In addition, economic studies of helium markets could benefit from better modeling of demand and uncertainty. Finally, there is a great need for more empirical work to estimate current demand elasticities and the responsiveness of helium supply and demand to recent decreases in the volumes of helium stored in the U.S. Federal Helium Reserve.

\section{ACKNOWLEDGMENTS}

The author appreciates the thorough and helpful reviews of Peter Warwick and Tina Roberts-
Ashby of the Eastern Energy Resources Science Center, U.S. Geological Survey; John DeYoung (Scientist Emeritus, National Minerals Information Center, U.S. Geological Survey); and two anonymous reviewers for Natural Resources Research. The author further would like to thank Sean Brennan (USGS Eastern Energy Resources Science Center) and John Hamak (Lead Petroleum Engineer, Helium Resources, U.S. Bureau of Land Management) for their insight and discussions. Use of trade, product, or firm names is for descriptive purposes only and does not imply endorsement by the U.S. Government.

\section{OPEN ACCESS}

This article is distributed under the terms of the Creative Commons Attribution 4.0 International License (http://creativecommons.org/licenses/by/4.0/), which permits unrestricted use, distribution, and re production in any medium, provided you give ap propriate credit to the original author(s) and the source, provide a link to the Creative Commons li cense, and indicate if changes were made.

\section{REFERENCES}

Air Products \& Chemicals, Inc. (2015). Air Products holds grand opening at its Doe Canyon helium plant-Facility is the world's first to produce helium from carbon dioxide stream. Lehigh Valley, PA: Air Products and Chemicals Inc. news release, August 19. Retrieved December 15, 2016, from http://www.airproducts.com/Company/news-center/2015/08/ 0819-air-products-holds-grand-opening-at-doe-canyon-he lium-plant.aspx.

American Physical Society, Materials Research Society, \& American Chemical Society. (2016). Responding to the U.S. Research Community's Liquid Helium Crisis-An action plan to Preserve U.S. Innovation. Washington, DC: American Physical Society, Materials Research Society, \& American Chemical Society.

APS Panel on Public Affairs \& Materials Research Society. (2011). Energy critical elements-Securing materials for emerging technologies (p. 24). Washington, DC: American Physical Society.

Baumol, W. J. (1968). On the social rate of discount. American Economic Review, 58(4), 788-802.

Brennan, S. T., East, J. A., II, Dennen, K. O., Jahediesfanjani, H., \& Varela, B. (2017) Geologic $\mathrm{CO}_{2}$ utilization-Data-Helium concentrations in United States Wells: U.S. Geological Survey. Retrieved November 1, 2017, from https://energy.usgs.gov/EnvironmentalAspects/Environmental AspectsofEnergyProductionandUse/GeologicCO2Utilization. aspx\#377624-data. 
Brown, A. A. (2010). Formation of high helium gases - A guide for explorationists. Tulsa, OK: American Association of Petroleum Geologists search and discovery article 80115, October 29.

Burton, S. R. M. (2017). Closure plans take shape for US Federal Helium Program. Lexington, Massachusetts. Gasworld US Edition, 56(11), 36-38.

Butler, D. (2017). Qatar blockade hits helium supply. Nature, $547(7661), 16$

Cai, Z., Clarke, R. H., Glowacki, B. A., Nuttall, W. J., \& Ward, N. (2010). Ongoing ascent to the helium production plateau-Insights from system dynamics. Resources Policy, $35,77-89$.

Cai, Z., Clarke, R. H., \& Nuttall, W. J. (2012). Helium demand-Applications, prices and substitution. In W. J. Nuttall, R. H. Clarke, \& B. A. Glowacki (Eds.), The future of helium as a natural resource (pp. 134-156). London: Routledge.

Carbon Capture \& Sequestration Technologies. (2016). LaBarge fact sheet-Carbon dioxide capture and storage project. Cambridge, MA: Carbon Capture \& Sequestration Technologies, MIT Energy Initiative, Massachusetts Institute of Technology. Retrieved December 16, 2016, from https://se questration.mit.edu/tools/projects/la_barge.html.

Capitol Forum. (2016). Praxair/Linde AG-On-site, merchant, issues drive antitrust risk; November election's results, FTC transition improve clearance odds. Washington, DC: The Capitol Forum, December 20. Retrieved June 1, 2017, from https://thecapitolforum.com/wp-content/uploads/2013/12/ Praxair-Linde-2016.12.20.pdf.

Clarke, R. H., \& Clare, R. (2012). Helium from the air-The backstop. In W. J. Nuttall, R. H. Clarke, \& B. A. Glowacki (Eds.), The future of helium as a natural resource (pp. 119133). London: Routledge.

Clarke, R. H., Nuttall, W. J., \& Glowacki, B. A. (2012). Introduction. In W. J. Nuttall, R. H. Clarke, \& B. A. Glowacki (Eds.), The future of helium as a natural resource (pp. 1-14). London: Routledge.

Clarke, R. H., Nuttall, W. J., \& Glowacki, B. A. (2013). Endangered helium-Bursting the myth. London, UK: The Chemical Engineer (870-871), December, 32-14. Retrieved December 15, 2016, from http://www.thechemicalengineer. $\mathrm{com} / \sim /$ media/Documents/TCE/free-features/870helium.pdf.

Cockerill, R. (2013). Harley Dome helium plant operating. Cornwall, UK: gasworld.com Ltd., October 24. Retrieved October 31, 2016, from https://www.gasworld.com/north-america/har ley-dome-helium-plant-operating/2002919.article.

Cook, E. (1979). The helium question. Science, 206(4423), 11411147.

Croce, B. (2017). Geopolitics threatens hydrogen economy, world helium supply. Lexington, Massachusetts. Gasworld US Edition, 55(7), 24-25.

Daly, H. (1977). Steady state economics-The economics of biophysical equilibrium and moral growth. San Francisco: W.H. Freeman Company.

Dasgupta, P. S., \& Heal, G. M. (1979). Economic theory and exhaustible resources (p. 501). Cambridge: Cambridge University Press.

Devarajan, S., \& Fisher, A. C. (1981). Hotelling's "Economics of Exhaustible Resources": Fifty years later. Journal of Economic Literature, 19(1), 65-73.

Dixit, A. K., \& Pindyck, R. S. (1994). Investment under uncertainty. Princeton, NJ: Princeton University Press.

DLA Strategic Materials. (2017). Strategic and critical materials operations report to Congress-Operations under the Strategic and Critical Materials Stock Piling Act during fiscal year 2016. Washington, DC: Office of the Under Secretary of Defense for Acquisition, Technology, and Logistics, U.S. Department of Defense.
Epple, D., \& Lave, L. B. (1980). Helium-Investments in the future. Pittsburgh, PA: Carnegie Mellon University, Tepper School of Business paper 1180, January 1. Retrieved March 26, 2014, from http://repository.cmu.edu/tep per/1180.

Exxon Mobil Corp. (2016). Financial and operating review 2015 (p. 94). Irving, TX: Exxon Mobil Corp.

Flower, A. (2012). LNG-The global liquefied natural gas market. In W. J. Nuttall, R. H. Clarke, \& B. A. Glowacki (Eds.), The future of helium as a natural resource (pp. 69-87). London: Routledge.

Forrester, J. W. (1951). Industrial dynamics. Cambridge, MA: MIT Press.

Gage, B. D., \& Driskill, D. L. (1998). Helium resources of the United States-1997. Amarillo, TX: Bureau of Land Management - Helium Operations, U.S. Department of the Interior.

Garvey, M. D. (2017). 2017 global helium market—Supply chain challenges remain. Lexington, Massachusetts. Gasworld US Edition, 56(11), 30-35.

gasworld (2014) Helium-Softening demand ahead? Lexington, Massachusetts: gasworld, 42-43.

gasworld Business Intelligence. (2017). Praxair-Linde-Potential divestments in focus. Lexington, Massachusetts. Gasworld US Edition, 55(7), 22-23.

Gazprom. (2017). Gas transmission and storage-Underground gas storage. Moscow, Russian Federation: Public Joint Stock Company Gazprom. Retrieved November 2, 2017, from http://www.gazprom.com/about/strategy/transportation/.

Goldberg, S. (2015). Profit from helium's price ascent. Wall Street Daily, July 31. Retrieved October 31, 2016, from https://www. wallstreetdaily.com/2015/07/31/helium-policy-prices/.

Hamak, J. E. (2016a). Helium [advance release]. In Metals and minerals: U.S. Geological Survey minerals yearbook 2014 (Vol. I, pp. 35.1-35.8). Retrieved December 6, 2016, from http://minerals.er.usgs.gov/minerals/pubs/commodity/helium/ myb1-2014-heliu.pdf.

Hamak, J. E. (2016b). Helium. In U.S. Geological Survey mineral commodity summaries 2016 (pp. 78-79).

Hamak, J. E. (2017). Helium. In U.S. Geological Survey mineral commodity summaries 2017 (pp. 78-79).

Healy, R. (2016). Air Liquide commissions the world's first helium storage facility in Germany. Cornwall, UK: gasworld.com Ltd., June 26. Retrieved November 2, 2017, from https:// www.gasworld.com/world-first-air-liquide-commissions-hestorage-site/2010766.article.

Hotelling, H. (1931). The economics of exhaustible resources. The Journal of Political Economy, 39(2), 137-175.

Howland, H. R., \& Hulm, J. K. (1974). The economics of helium conservation, final report to Argonne National Laboratory, contract No. 31-109-38-2820. Appendix C in C. Laverick, Heliu$m$-Its storage and use in future years (pp. C1-C171). Argonne, IL: Argonne National Laboratory Report ANL/EE-75-1.

Hughey, A. M. (1989). Uncertainty and the joint extraction of helium and natural gas. Resources and Energy, 11(1), 65-79.

Hughey, A. M. (1991). Joint natural resources and government policy-Helium and natural gas. Eastern Economic Journal, 17(1), 80-88.

IACX Energy LLC. (2016). Helium projects. Houston, TX: IACX Energy LLC. Retrieved December 16, 2016, from http://iacx. com/helium-projects/.

IHS Markit. (2016a). Global helium market swings to oversupply following supply constraints and demand destruction-IHS Markit says. London, UK: IHS Markit Ltd., November 7. Retrieved December 15, 2016, from http://news.ihsmarkit. com/press-release/ceh-reports/global-helium-market-swingsoversupply-following-supply-constraints-and-0.

IHS Markit. (2016b). Helium. In Chemical economics handbook. London, UK: IHS Markit Ltd., April. Retrieved May 4, 2016, 
from https://www.ihs.com/products/helium-chemical-econom ics-handbook.html.

Jaskula, B. W. (2016). Lithium. In U.S. Geological Survey mineral commodity summaries 2016 (pp. 100-101).

Jensen, M. C., \& Bailey, M. J. (1972). Risk and the discount rate for public investment. In M. C. Jensen (Ed.), Studies in the theory of capital markets. New York, NY: Praeger Publishers.

Kinder Morgan Inc. (2015). Kinder Morgan increases quarter dividend to $\$ 0.48$ per share-Up $14 \%$. Houston, TX: Kinder Morgan Inc. press release, April 15. Retrieved December 16 2016, from http://ir.kindermorgan.com/press-release/all/kin der-morgan-increases-quarterly-dividend-048-share-14.

Kinder Morgan Inc. (2017). Annual report on Form 10-K for the fiscal year ended December 31, 2016. Houston, TX: Kinder Morgan Inc.

Kornbluth, P. (2015). Evolution of the global helium business-1990-2015. Cornwall, UK: CryoGas International, September (pp. 34-36). Retrieved January 12, 2016, from http://www.kornbluthheliumconsulting.com/images/CryoGa sArticle-Final.pdf.

Kornbluth, P. (2016). Helium-A market update. Cornwall, UK: gasworld.com Ltd., January 6 (pp. 38-41). Retrieved January 12, 2016, from http://www.kornbluthheliumconsulting.com/ images/HeUpJan16.pdf.

Kornbluth, P. (2017a). Helium Extraction Act of 2017 aims to ease the path to new US sources. Cornwall, UK: gasworld.com Ltd., June 22. Retrieved July 27, 2017, from https://www.gas world.com/helium-extraction-act-of-2017-aims-to-boost-sour cing/2013006.article.

Kornbluth, P. (2017b). Helium supply chain disrupted as Qatar blockade continues to challenge exports. Lexington, Massachusetts. Gasworld US Edition, 55(8), 6-7.

Kornbluth, P. (2017c). Praxair-Linde merger-Major new helium competitor. Lexington, Massachusetts. Gasworld US Edition, 56(11), 40-41.

Liu, B. (1983). Helium conservation and supply and demand projections in the USA. Energy Economics, 5(1), 58-64.

Macal, C. M. (2010) To agent-based simulation from system dynamics. In B. Johansson, S. Jain, J. Montoya-Torres, J. Hugan \& E. Yücesan (Eds.) Proceedings of the 2010 Winter Simulation Conference (pp. 371-382), December 5-8, 2010. Baltimore, MD: IEEE.

Martin, R. (2015). Quest to mine seawater for lithium advances. Cambridge, MA: MIT Technology Review, June 8. Retrieved October 14, 2015, from https://www.technologyreview.com/s/ 538036/quest-to-mine-seawater-for-lithium-advances/.

Massol, O., \& Rifaat, O. (2016). Phasing out the U.S. Federal Helium Reserve-Policy insights from a world helium model. Montpellier, France: French Association of Environmental and Resource Economists, FAERE Working Paper, 2016.29, November 11.

McDonald, L. (2017). Representatives look to shore up Nation's helium supply. College Park, MD: American Institute of Physics, FYI Report 90 June 30. Retrieved July 29, 2017, from https://www.aip.org/fyi/2017/representatives-lookshore-nation $\% \mathrm{E} 2 \% 80 \% 99$ s-helium-supply.

Mohr, S., \& Ward, J. (2014). Helium production and possible projection. Minerals, 4(1), 130-144.

National Aeronautics and Space Administration. (2017). Flight hardware for NASA's space launch system on its way to Cape. Washington, DC: National Aeronautics and Space Administration News. Retrieved August 6, 2017, from https://www. nasa.gov/exploration/systems/sls/multimedia/flight-hardwarefor-sls-on-its-way-to-cape.

National Research Council. (2000). The impact of selling the Federal Helium Reserve. Washington, DC: National Academics Press, National Academy of Sciences.
National Research Council. (2010). Selling the nation's helium reserve (p. 156). Washington, DC: National Academies Press, National Academy of Sciences.

Newell, K. D., Bhattacharya, S., \& Sears, M. S. (2009). Low-BTU gas in the US Midcontinent-A challenge for geologists and engineers. Oil and Gas Journal, 107(36), 35-44.

Nordhaus, W. D. (1973). The allocation of energy resources. Brookings Papers on Economic Activity, 4(3), 529-576.

Nuttall, W. J., Cai, Z., Glowacki, B. A., Kazantzis, N., \& Clarke, R. H. (2012). The dynamics of the helium market. In W. J. Nuttall, R. H. Clarke, \& B. A. Glowacki (Eds.), The future of helium as a natural resource (pp. 157-173). London: Routledge.

Oil \& Gas Journal. (2013). Eastern Utah Harley Dome helium plant starts up. Houston, TX: Oil \& Gas Journal, October 17. Retrieved October 31, 2016, from http://www.ogj.com/arti cles/2013/10/eastern-utah-harley-dome-helium-plant-starts-up. html.

Pacheco, N. (2008). Helium. In U.S. Geological Survey mineral commodity summaries 2008 (pp. 78-79).

Pacheco, N. (2009). Helium. In U.S. Geological Survey mineral commodity summaries 2009 (pp. 74-75).

Page, T. (1977). Conservation and economic efficiency (p. 288). Baltimore, MD: Johns Hopkins University Press.

Passut, C. (2015). Kinder Morgan withdraws application for Lobos $\mathrm{CO}_{2}$ pipeline. Dulles, VA: Natural Gas Intelligence, February 6. Retrieved December 16, 2016, from http://www.natur algasintel.com/articles/101292-kinder-morgan-withdraws-appli cation-for-lobos-co2-pipeline.

Pigou, A. C. (1929). The economics of welfare (3rd ed.). London: Macmillan.

Pindyck, R. S. (1982). Jointly produced exhaustible resources. Journal of Environmental Economics and Management, 9, 291-303.

PRNewswire. (2013). IACX Energy announces the start-up of the Harley Dome helium plant. Dallas, TX: PRNewswire, October 17. Retrieved December 16, 2016, from http://www. prnewswire.com/news-releases/iacx-energy-announces-thestart-up-of-the-harley-dome-helium-plant-228156001.html.

Rauzi, S. L. (2003) Review of helium production and potential in Arizona. Tucson, AZ: Arizona Geological Survey open-file report OFR 03-05, October, 29 p.

Reisch, M. S. (2017a). Helium shortage looms. Chemical \& Engineering News, 95(26), 11. Retrieved July 27, 2017, from http://cen.acs.org/articles/95/i26/Helium-shortage-looms.html

Reisch, M. S. (2017b). More helium is on the way. Chemical \& Engineering News, 95(30), 22-23. Retrieved July 27, 2017, from http://cen.acs.org/articles/95/i30/helium-way.html.

Riddle, M., Uckun, C., Conzelmann, G., \& Macal, C. (2016). Development of an agent-based model to analyze contemporary helium markets. Chicago, IL: Argonne National Laboratory report ANL/ESD-16/5, February, $15 \mathrm{p}$.

Sears, B. (2012). A history of the helium industry. In W. J. Nuttall, R. H. Clarke, \& B. A. Glowacki (Eds.), The future of helium as a natural resource (pp. 15-47). London: Routledge.

Shea, D. A., \& Morgan, D. (2010). The Helium-3 shortage-Supply, demand, and options for Congress. Washington, DC: Congressional Research Service.

Society of Petroleum Engineers. (2017). Petroleum reserves and resources definitions. Retrieved July 25, 2017, from http:// www.spe.org/industry/reserves.php.

Solow, R. M. (1974). The economics of resources or the resources of economics. American Economic Review, 64(2), 1-14.

Sterman, J. D. (2000). Business dynamics-Systems thinking and modeling for a complex world (p. 982). Boston, MA: McGraw-Hill. 
Subcommittee on Energy and Mineral Resources. (2017). Legislative hearing on discussion draft of H.R. "Helium Extraction Act of 2017'. Washington, DC: Subcommittee on Energy and Mineral Resources, Committee on Natural Resources, United States House of Representatives. Accessed June 21, 2017, at https://naturalresources.house.gov/calendar/ eventsingle.aspx?EventID=402158.

Tietenberg, T. H. (2003). Environmental and natural resource economics (6th ed.). New York, NY: Addison Wesley.

Trager, R. (2017). Linde-Praxair merger further consolidates industrial gases. London, UK: The Royal Society of Chemistry, Chemistry World, January 9. Retrieved June 1, 2017, from https://www.chemistryworld.com/news/lindepraxairmerger-further-consolidates-industrial-gases/2500223.article.

Uri, N. D. (1986). The helium market in the USA. Applied Energy, 22(1), 15-30.

Uri, N. D. (1987). Helium conservation-Supply and demand conditions in the USA reconsidered. Energy Economics, 9(2), 93-98.

U.S. Bureau of Land Management. (2014a). FY2015 conservation crude helium sale: U.S. Bureau of Land Management, August 14. Retrieved December 12, 2016, from https://www.blm.gov/ programs/energy-and-minerals/helium/federal-helium-opera tions.

U.S. Bureau of Land Management. (2014b). Helium Phase B Auction: U.S. Bureau of Land Management, July 30. Retrieved December 12, 2016, from https://www.blm.gov/programs/en ergy-and-minerals/helium/federal-helium-operations.

U.S. Bureau of Land Management. (2015). FY2016 conservation crude helium sale: U.S. Bureau of Land Management, October 6. Retrieved December 12, 2016, from https:/www.blm.gov/pro grams/energy-and-minerals/helium/federal-helium-operations.

U.S. Bureau of Land Management. (2016). FY2017 conservation crude helium sale: U.S. Bureau of Land Management, August 30.
Retrieved December 12, 2016, from https://www.blm.gov/pro grams/energy-and-minerals/helium/federal-helium-operations.

U.S. Bureau of Mines \& U.S. Geological Survey. (1980). Principles of a resource and reserve classification for minerals. Washington, DC: U.S. Geological Survey Circular 831, 5 p.

U.S. Energy Information Administration. (2016). Today in energy-Growth in domestic natural gas production leads to development of LNG export terminals: U.S. Energy Information Administration, March 4. Retrieved January 26, 2017, from http://www.eia.gov/todayinenergy/detail.php?id= 25232.

U.S. Geological Survey. (2017). Appendix C-Reserves and resources. In U.S. Geological Survey mineral commodity summaries 2017 (pp. 197-199).

U.S. Government Accountability Office. (2015). Bureau of Land Management - More information needed to implement the Helium Stewardship Act of 2013, GAO-15-394, April 16, 36 p. Retrieved May 3, 2016, from http://www.gao.gov/assets/670/669709.pdf.

U.S. Government Printing Office. (2013). Public Law 11340-Oct. 2, 2013-Helium Stewardship Act of 2013. Washington, DC: U.S. Government Printing Office. Retrieved March 21, 2014, from https://www.congress.gov/113/plaws/ publ40/PLAW-113publ40.pdf.

Varian, H. R. (1990). Intermediate microeconomics - A modern approach. New York, NY: W.W. Norton \& Company Inc.

Waltenberg, K. (2013). Preliminary draft-Helium as a critical commodity. Canberra: Geoscience Australia Record.

Whiticar, M. J. (1994). Correlation of natural gases with their sources. In L. B. Magoon \& W. G. Dow (Eds.), The petroleum system-From source to trap, AAPG Memoir 60 (pp. 261-283). Tulsa, OK: The American Association of Petroleum Geologists.

Zahnle, K. J., \& Catling, D. C. (2009). Our planet's leaky atmosphere. Scientific American, 300(5), 35-43. 